TOPIC II.A.2

\title{
HERBERT BERNSTEIN
}

\section{Civil Liability for Pure Economic Loss Under American Tort Law}

\section{INTRODUCTION}

Under the American federal system, liability for a tort (delictual liability) is governed mainly by state law, not federal law. As an exception to this rule, maritime torts are governed by federal law. Consequently, and since each of the 50 states has its own law of torts, all of the statements made in this paper with respect to liability for pure economic loss under American law must be understood as generalizations (abstractions) which may not fully reflect the statutory and/or case law in any individual state of the United States.

In the most general of terms, it can be said that purely economic loss is not recoverable under American tort law rules of negligence. That, however, does not mean that economic losses can never be recovered in a negligence case, e.g., in a case where the plaintiff suffers both physical injury and economic loss. For example, a loss of wages resulting from personal injury to the plaintiff may well be recoverable. Similarly, the loss of rent resulting from physical damage to the plaintiff's tangible property may be recoverable. In these instances, the plaintiff would be claiming "consequential damages" 1 attributable to an event which constitutes a tort, provided certain requirements, such as negligence, causation, absence of excuses, etc., are met. Thus there would be a basis for liability; the only remaining question would involve the extent of liability. And thus the main issue in this type of case would be whether economic consequences of personal injury or damage to tangible property need to be foreseeable or meet some other test, before such loss can be recovered.

Herbert Bernstein is Professor of Law, Duke University School of Law. The author is most grateful to Professor dr.jur. Joseph Lookofsky, University of Copenhagen, friend, colleague and collaborator, for reading and commenting on an earlier version of this paper.

1. As to this concept and its application in various legal systems, see Joseph Lookofsky, Consequential Damages in Comparative Context (1989). For some strange reason, consequential damages are also called "parasitic;" see Prosser and Keeton on the Law of Torts $\S 43$, at 291 (W. Keeton, $5^{\text {th }}$ ed. 1984). 
When, however, we speak of pure economic loss, we generally refer to situations in which the plaintiff has neither suffered personal injury nor damage to tangible property. In these instances American law is generally opposed to recovery on a negligence theory. But this no-liability rule has not gone uncriticized and is not without important exceptions. Various theoretical approaches have been suggested to rationalize the rule as well as the exceptions. Courts have also been criticized for occasionally allowing an exception that appears unjustified or, on the other hand, for applying the rule where an exception should have been made. The rule as such, however, and the need for certain exceptions are generally accepted by most legal commentators.

The first part of this paper will discuss the rule of no-liability and the exceptions to this rule, as they emerge from the relevant case law. In view of the limited space available, only the more important lines of fairly recent cases will be analyzed. In its second part the paper will outline some of the arguments American authors have developed in their discourse (la doctrine) involving the legal treatment of pure economic loss.

\section{CASe Law}

A leading 20th century case reaffirming the traditional rule which bars recovery for pure economic loss in negligence, is Robins Dry Dock \& Repair Co. v. Flint, ${ }^{2}$ a 1927 Supreme Court opinion by Justice Holmes. In this maritime case the time charterers of a ship claimed damages for the loss of use of the ship from the defendant, a dry dock company. The ship had been delivered to the defendant under the terms of the charter party which provided for its docking every six months. While so docked, the ship's spare propeller was negligently damaged by the defendant during installation and had to be replaced. As a consequence of the resulting delay in the return of the ship, plaintiffs suffered a loss of use and income. Based on a finding that the ship had remained in the owners' possession while chartered under a time charter, the court rejected an analogy with cases involving bailees and held that the plaintiffs had no "property right" in the ship. Since it was also found that the plaintiffs were not third-party beneficiaries of the defendant's contract with the shipowners, the court concluded: "The injury to the propeller was no wrong to the respondents [= plaintiffs], but only to those to whom it belonged." The court noted that, arguably, the shipowners could have recovered the plaintiffs' loss, acting as the plaintiffs' trustees in the process of recovering for the full loss of use. But instead of claiming damages for the entire loss including the plaintiff's loss of use (alleg-

2. See 275 U.S. 303 (1927). 
edly worth more than $\$ 33,000$ ), the owners had reached a settlement with the defendant in the amount of little more than $\$ 3,000$ and had given it a release from all claims. ${ }^{3}$ In these circumstances, the plaintiffs, who themselves had no contract with the defendant, were denied direct recovery for their loss - a loss which the court saw as "pure economic loss."

As the just-qoted passage shows, the U.S. Supreme Court relied heavily on the traditional Common Law view that a tortious wrong presupposes the violation of a "duty" owed to the plaintiff by the defendant. According to the court, in cases involving damage to property such a duty is owed only to those who have a right in rem with respect to the damaged piece of property. Consequently, someone entitled to its use merely by virtue of a contract right is not directly protected by the tort law rules of negligence.

For essentially the same reasons, employers have been denied recovery against negligent defendants for economic losses suffered as a consequence of injury to the plaintiff's employee. ${ }^{5}$ If, however, a family member or spouse, as distinguished from an employer, is deprived of the services and/or the support of a person negligently injured or killed, he or she may have a cause of action. This would result from some ancient form of action called per quod consortium amisit or, in case of death, from a more modern statutory cause of action under a Wrongful Death Act. Actually, the harm suffered by the plaintiff in these cases can be viewed as "pure economic loss." And yet this loss becomes recoverable, once a statute says so or when some corresponding judge-made concept comes into play, like that of consortium, which helps the plaintiff to rely on the violation of a quasi-proprietary right or "status" whose violation can be conceptualized as having occurred simultaneously with the injury to the principal victim. In fact, in the past even an employer (then called a "master") could use a related form of action, per quod servitium amisit, to claim damages for injuries negligently inflicted on his "servant" - an employee, in contemporary terminology. ${ }^{6}$ Most American

3. See Flint v. Robins Dry Dock \& Repair Co., 13 F.2d 3 (2d Cir. 1926). It appears from the Court of Appeals opinion that, at the time of the settlement, the defendant had notice of the plaintiffs' charter and their claim; thus the settlement seems to have been intended to cover only the owners' loss. The amount of the settlement probably represented the rent the plaintiff-charterers did not have to pay to the owner, and the owners thus did not receive, for the time of the delay.

4. For criticism of this characterization, see infra text at $n .96$.

5. See, for example, The Federal No. 2, 21 F.2d 313 (2d Cir. 1927). This case involved expenses for the care and cure of a seaman. In a related line of cases increased workers' compensation payments could not be recovered by the employer.

6. For a recent case summarizing the history of the cause of action since Roman times, see Morton v. Merrillville Toyota, Inc. 562 N.E. $2 d 781$ (Ct. App. Ind. 1990). As discussed in the opinion, some American courts extended the action beyond the realm of household employees; id. at 784 . 
states have abolished the action, ${ }^{7}$ but it seems that in a few states it is still available, or at least was still available fairly recently. ${ }^{8}$

Do the cases where an employer or a family member recovers for the loss of services owed by the victim of a tortious injury on a theory of per quod consortium amisit or per quod servitium amisit, stand for an exception to the principle that negligently caused pure economic loss is not recoverable? From a strictly doctrinal point of view the principle could be said to remain intact, since the loss that would otherwise be purely economic is said to be transformed into a consequential loss resulting from a tort committed against the plaintiffemployer (or family member). The construct of a quasi-proprietary right or "status" attributed to the plaintiff is the mechanism which performs this miracle. Given such a right or "status," the plaintiff is no longer seen as claiming recovery for a pure economic loss resulting from a tort committed against the property or the person of another. Rather, the plaintiff's own legal position is viewed as the object of a concomitant tort. Since, unlike any ordinary party to a contract, the plaintiff enjoys an "in-rem" (property) right, he or she is protected "against the whole world" by the rules of tort law.

So, at least on a doctrinal level, the results in the foregoing cases can be rationalized consistently with the principle of non-liability for pure economic loss. There are, however, numerous cases in which genuine exceptions to the principle have been carved out, and there are some in which even the principle itself has been questioned. Most, if not all of these cases can be grouped by subject-matter in the sense of typical fact patterns. From another perspective, a geographical grouping might appear to be meaningful, because there are a number of states whose courts have gone further than the majority in allowing recovery for pure economic loss. Since these two groupings do overlap, they will have to be combined in the following analysis.

\section{A. Intellectual Services}

Accountants, lawyers, architects and other professionals who provide primarily intellectual services (information, advice, plans etc.), do so ordinarily on the basis of a contract. If the client is disappointed with the quality of the service and a financial loss is arguably attributable to the service as rendered, the client may have a cause of action for breach of contract, and perhaps also for malpractice. Some-

7. See id. at 784 and Mattingly v. Sheldon Jackson College, 743 P.2d 356, 361-63 (Alas. 1987).

8. In Offshore Rental Co. v. Continental Oil Co. 583 P. 2d 721 (Cal. 1978), as recently as 20 years ago, the California court had to resolve a conflict-of-laws issue resulting from the continued validity of the old rule in California and its non-existence in Louisiana. But see also Weinrot v. Jackson, 708 P.2d 682 (Cal. 1985), a case in which the California Supreme Court limited application of the old cause of action to domestic servants. 
times, however, a person other than the client claims to have suffered a loss as a consequence of poorly/negligently rendered intellectual services. Can such a third party recover in a negligence action?

Earlier in this century it appeared that at least some prominent and influential American judges were inclined to allow recovery in these cases in a variety of circumstances. In Glanzer $v$. Shepard ${ }^{9}$ a seller of beans had contracted with a professional weigher for the beans to be weighed and a weight certificate to be issued. The plaintiff-buyer had paid the price in accordance with the weight so certified and later discovered that the real weight was less. The New York Court of Appeals, in an opinion by Judge Cardozo, allowed the plaintiff-buyer to recover in a negligence action against the weigher on the theory that the buyer's conduct (paying the price in reliance on the certificate) was "the end and aim of the transaction."

Only nine years later the New York court, this time speaking through Chief Judge Cardozo, made it clear that Glanzer was to be read quite narrowly. In Ultramares Corp. $v$. Touche $e^{10}$ the defendantsaccountants had audited a business and supplied it with 32 certified copies of the balance sheets based on the company's books. The problem was that the books (i.e., the basis on which the balance sheets were prepared) had been falsified by those in charge of the business. Thus, although the balance sheet showed a net worth of $\$ 1$ million, the company was actually insolvent. After the plaintiff had received one of the certified copies of the balance sheet, the plaintiff extended credit to the company and-as a consequence of its reliance on the sheet-suffered an economic loss. The complaint alleged negligent (and also fraudulent) misrepresentation by the defendant. While in the court's view the jury might well find the defendants to have acted negligently, the court distinguished Glanzer and held that the transmission of the balance sheet to the plaintiff in Ultramares was not the "end and aim of the transaction." Even though the defendants were found to have known that the certified balance sheet would be exhibited to banks, creditors, stockholders, etc. as the basis of financial dealings, the Ultramares-defendants did not know the identity of these persons and the extent or number of the transactions in which the balance sheet would be used. In this situation the court was unwilling to impose liability for negligence, because doing so might "expose accountants to a liability in an indeterminate amount for an indeterminate time to an indeterminate class."11

More than fifty years later the New York Court of Appeals reaffirmed its narrow interpretation of the exception to the principle of no liability for pure economic loss in the case of accountants and similar

9. See 135 N.E. 275 (N.Y. 1922).

10. See 174 N.E. 441 (N.Y. 1931).

11. Id. at 444 . 
service providers by restating the test of "quasi-privity" embraced by the Glanzer-Ultramares pair of cases. ${ }^{12}$ It may even have tightened this test by emphasizing the "nexus" or "bond" between the plaintiff and the defendant that, according to those precedents, are required for the imposition of liability in a case of negligence. ${ }^{13}$ The court now requires "some conduct on the part of the accountants linking them to [the plaintiff], which evinces the accountants' understanding of [the plaintiff's] reliance."14 It appears as if nine states follow New York's "quasi-privity" approach. ${ }^{15}$

The Restatement Second of Torts, on the other hand, and a number of American jurisdictions have taken a more liberal position. Instead of insisting on "quasi-privity" between the parties, the crucial test under this approach is satisfied if the defendant supplied information for the guidance of others in their business conduct and plaintiff belongs to a group of persons which the defendant knew would receive the information generated by the defendant, provided the loss-causing transaction based on the information is, at least, similar to the one the defendant intended to influence. ${ }^{16}$ It seems that at least 17 state and federal decisions had adopted the Restatement's "intended beneficiary model" by $1992 .{ }^{17}$ At that time the Supreme Court of California joined this group in a carefully reasoned opinion. ${ }^{18}$

The limited exceptions from the rule barring recovery for pure economic loss have been criticized as providing "anachronistic protection" for accountants, and the application of a mere "foreseeability" test has been suggested for these cases. ${ }^{19}$ Heeding this criticism, the New Jersey Supreme Court adopted the foreseeability approach 15 years ago, subject to certain provisos applicable to institutional investors. ${ }^{20}$ Apparently, only two other state supreme courts have endorsed a foreseeability analysis in cases of auditor-negligence, and most commentators have criticized the alleged propensity of the ap-

12. See Credit Alliance Corp. v. Arthur Anderson \& Co., 483 N.E.2d 110 (N.Y 1985). "Quasi-privity" refers to a requirement approaching that of a contractual relationship.

13. See Ultramares, supra n. 10 , at 445,446 distinguishing Glanzer, supra n. 9 .

14. Credit Alliance case, supra n. 12, at 118 .

15. For details, see citations in Bily v. Arthur Young \& Co., 834 P.2d 745, 755 (Cal. 1992),

16. See Restatement Second of Torts $\S 552$.

17. See the Bily case, supra $n$. 15 , at 759 .

18. See the Bily case, supra n. 15.

19. See Wiener, "Common Law Liability of the Certified Public Accountant for Negligent Misrepresentation," 20 San Diego L. Rev. 233 (1983). In the author's view, foreseeablity in these cases is to be treated as a question of fact for the jury.

20. See Rosenblum v. Adler, 461 A.2d 138 (N.J. 1983). Arguably, the plaintiff in this case could have recovered even under the Restatement test. Note also that, on the other hand, the foreseeability approach, as interpreted by the New Jersey court, protects only parties who received the audit from the company for the purpose of influencing their conduct; see id. at 153. 
proach to engender indeterminate liability and the problematic effect of deterrence that proponents of the approach expect to follow from it. $^{21}$

While the liability of accountants has attracted more attention than that of any other branch in the intellectual service industry, there are also cases involving the liability of attorneys and other legal professionals for pure economic loss of third parties. A leading case is Biakanja $v$. Irving, ${ }^{22}$ in which a notary public had agreed to prepare a will and negligently failed to have it properly attested by two witnesses. As a consequence, the plaintiff, the testator's sister, who would have been the sole heir under the will received only one-eighth of the estate. The court held the defendant-notary liable in a negligence action stating that the question of liability was a matter of policy to be determined by balancing various factors. Among them the court mentioned the extent to which the transaction was intended to affect the plaintiff, the foreseeablity of harm to her, the degree of certainty that she would suffer injury, the "closeness" of defendant's conduct and the injury suffered, the degree of moral blame attached to defendant's conduct and the policy of preventing future harm. ${ }^{23}$ Referring to the Glanzer case, the court emphasized that here the "end and aim" of the transaction was to provide for the passing of the decedent's estate to the plaintiff. ${ }^{24}$

In subsequent cases the California court applied the rule which the first case developed for a notary public to attorneys who, in similar circumstances, were held liable for the pure economic loss of the "intended beneficiary" of a last will and testament which, because of the defendant's negligence, had failed to accomplish the intended purpose. ${ }^{25}$ Where, however, the defendant-lawyer's service was not intended to benefit the third-party plaintiff, the court has denied liability. ${ }^{26}$ It reasoned that in cases in which the client deals with other parties at arm's length, imposing liability to the third party on the attorney "would inject undesirable self-protective reservations into the attorney's counseling role."27 It applied this reasoning, for example, to a case in which a lawyer had erroneously advised a small corporation and its managers that certain stock they planned to issue

21. For details, see the Bily case, supra n. 15, at 757 .

22. 320 P.2d 16 (Cal. 1958).

23. Id. at 19 .

24. Id.

25. See Lucas v. Hamm, 364 P.2d 685 (Cal. 1961), Heyer v. Flaig, 449 P.2d 161 (Cal. 1969).

26. See Goodman v. Kennedy, 556 P.2d 737 (Cal. 1976), Johnson v. Superior Court 45 Cal. Rptr.2d 312 (Ct.App. 1995).

27. Goodman case, previous note, at 743. For a discussion of policy issues and case law, see Feinman, "Attorney Liability to Nonclients," 31 Tort \& Ins. L J. 735 (1996) and, from a more general perspective, Jay M. Feinman, Economic Negligence (1995). 
did not require registration under federal law. After the stock had been issued and investors had purchased it, the S.E.C. insisted on registration which decreased the value of the stock. The investors, however, were denied recovery for their pure economic loss. ${ }^{28}$

\section{B. Defective Products}

The law pertaining to liability for defective products has undergone profound changes in the last four decades, both in the United States and elsewhere. As a result, American courts are now routinely imposing liability for negligence and strict liability in tort (delict) on manufacturers and distributors of defective products in cases in which a product has caused physical harm to person or property. In addition, the law of sales may provide the plaintiff with a "contractual" remedy for breach of warranty, at least in certain circumstances. Obviously, the tort remedy does not require the plaintiff to be in "privity," i.e., in a contractual relationship, with the defendant. And under the law of most American states, the warranty claim may be available even in the absence of privity between the parties, as it is traditionally understood. ${ }^{29}$

Much controversy has arisen with respect to the question of whether "pure economic loss" can be recovered in a products liability action. Once again it needs to be emphasized that economic loss resulting from personal injury caused by the product is not pure economic loss in this sense; it is thus, in principle, recoverable on a tort theory together with compensation for the personal injury itself. The same is true in cases involving damage to property other than the defective product itself. Recovery can be had not only for the harm to that piece of property, ${ }^{30}$ but ordinarily also for consequential losses, such as profits lost because the damaged item of property, for instance a machine in the plaintiff's factory, could not be used for its usual productive purpose. ${ }^{31}$

The continuing controversy involves the question whether economic loss can be recovered on a non-contractual basis when that loss consists solely of harm to the defective product itself and consequential economic losses resulting therefrom. One of the early cases is

28. Goodman case, supra n. 26.

29. See Uniform Commercial Code $\S 2-318$ Alternatives A to C. Note that the law of the various states of the United States respecting the "privity" requirement under a seller's warranty is not uniform.

30. Occasionally, a statute will preclude tort recovery for such damage in a sale between merchants; see Minn. Stat. Ann. $\S 604.10$ (a) (West 1994). For cases, see Hapka v. Paquin Farms, 458 N.W.2d 683 (Minn. 1990), Lloyd F. Smith Co. v. DENTAL-EZ Inc. 491 N.W.2d 11 (Minn. 1992).

31. As to the foregoing, see Restatement Third of Torts, Proposed Final Draft (1997), $\S 21$ (a) and (c). The extent to which such loss can be recovered in a concrete case is governed by general principles of causation, etc.; see Restatement Second of Torts $\$ \S 430-461$. 
Seely v. White Motor Co. in which Chief Justice Traynor wrote the opinion for the California Supreme Court. ${ }^{32}$ In this case the plaintiffbuyer sought to hold the defendant-seller of a truck liable for money already paid on the purchase price, and for repair costs as well as lost profits that he had incurred because the truck's defective brakes had caused the vehicle to overturn. The court denied recovery under strict (tort) products liability on the ground that a product's failure to perform according to the buyer's expectations is a matter exclusively regulated by the law of warranty. The court was concerned that imposing strict liability in tort for harm to the product itself and economic losses resulting therefrom would tend to undermine the protection built into the law of warranty. It would expose the manufacturer, as the court put it, to liability for damages of "unknown and unlimited scope" since "the manufacturer would be liable even though it did not agree that the product would perform as plaintiff wished or expected it to do." 33

Even though the views expressed by the California court in Seely are shared by the majority of jurisdictions, a minority of courts allow tort recovery for pure economic loss in defective product cases under certain conditions. In a New Jersey case the plaintiff had purchased a carpet described as "\#1grade" which turned out to be defective in that two unusual lines appeared in it. It did not, however, damage other property; nor did it create an unreasonable (or any) risk of harm. Nonetheless, the court allowed the plaintiff to recover from the manufacturer for the "loss of bargain," i.e., the diminished value of the carpet, both on a warranty and a strict tort liability basis. ${ }^{34}$ The courts in the minority are satisfied that safety and insurance rationales justify strict liability for pure economic loss just as much as strict liability for personal injury and property damage resulting from product defects.

While the extreme position of the New Jersey court in Santor is probably not endorsed by many jurisdictions, there is a sizeable group of courts which hold that tort rules (strict liability or negligence) should govern liability for pure economic loss where a product, without causing personal injury or damage to other property, causes a loss by an "accident-like" event, sometimes described as a "sudden and calamitous" occurrence. It is argued that in such a situation the product is shown to be dangerous and not only ineffective, and thus

32. See 403 P.2d 145 (Cal.1965).

33. Id. at $149,150$.

34. See Santor v. A \& M Karagheusian, Inc., 207 A.2d 305 (N.J. 1965). The House of Lords has taken the same position with respect to the installation of a defective floor in Junior Books, Ltd. v. Veitchi Co. Ltd. [1983] 1 App. Cas. 520 (1982); but it seems to have withdrawn from this position in more recent cases. See Christie, "The Uneasy Place of Principle in Tort Law," 49 SMU L. Rev. 525, 531-36 (1996). 
the plaintiff is not merely a disappointed user, but rather an endangered user who should be allowed to sue in tort. ${ }^{35}$

Significantly, the Supreme Court of the United States had occasion to pronounce on the recovery of "pure economic loss"-at least as it applies to maritime cases-in 1986. A unanimous court, in an opinion by Justice Blackmun that influenced the development of the law well beyond maritime law, found "the intermediate and minority land-based positions unsatisfactory." 36 Consequently, the court adopted the Seely position and repeated, in essence, the reasoning of Chief Justice Traynor. ${ }^{37}$ In this case bare boat charterers of several supertankers were seeking damages from the manufacturer of the ships' turbine engines that had malfunctioned and thus necessitated repairs resulting in sizeable costs and loss of profits. The court held "that a manufacturer in a commercial relationship has no duty under either a negligence or strict products-liability theory to prevent a product from injuring itself." 38 According to the U.S. Supreme Court, in cases of an ineffective product or harm to the product itself the public policy concern with safety is reduced and the damage most naturally understood as a claim under warranty law which sufficiently protects the purchaser. ${ }^{39}$ The court emphasized the built-in limitations on warranty actions resulting from the agreement of the parties and the requirement under Hadley v. Baxendale 40 that consequential damages must be a foreseeable result of the breach. By contrast, the court remarked, making the manufacturer liable for all foreseeable purely economic loss would impose liability for "vast sums." 41

Technically, the East River ruling is not binding in cases outside of maritime law. Nonetheless, it has had an extraordinary influence on state courts in ordinary product liability cases. ${ }^{42}$ But it has also encountered severe criticism. ${ }^{43}$ Note, moreover, that the opinion's denial of tort recovery, in cases where a defective product causes no

35. See, for example, two Alaska cases: Northern Power \& Engineering Corp. v. Caterpillar Tractor Co., 623 P.2d 324 (1981) and Kodiak Elec. Ass'n v. Delaval Turbine, Inc., 694 P.2d 150 (1984). In addition, see cases cited in Restatement Third of Torts, Proposed Final Draft, § 21, Reporter's Note pp. 379, 380.

36. See East River Steamship Corp. v. Transamerica Delaval, Inc. 476 U.S. 858, 870 (1986). The "minority land-based position" refers to the Santor approach, while the "intermediate land-based position" refers to the case law that uses the "sudden and calamitous" event approach. All of these approaches deal with "land-based," as distinguished from maritime, cases.

37. See supra text at nn. 32, 33 .

38. East River case, supra n. 36 , at 871 .

39. Id. at $871,872,873$.

40. 156 Eng.Rep.145 (Ex. 1854).

41. East River case, supra n. 36 , at 874 .

42. For a list of cases following East River, see Restatement Third of Torts, Proposed Final Draft (1997), §21, Reporter's Note, pp. 373-79.

43. See, for example, Swanson, "The Citadel Survives a Naval Bombardment: A Policy Analysis of the Economic Loss Doctrine," 12 Mar. Law. 135 (1987). 
personal injury or damage to other property, is limited to what the opinion calls the "commercial user." This would seem to leave open the possibility of a different result in consumer cases. The Supreme Court of New Jersey has pointed the way for such a differentiated treatment. Already before the East River case was decided, that court held its minority view of Santor ${ }^{44}$ inapplicable to a commercial setting, and the U.S. Supreme Court took note of this distinction. ${ }^{45} \mathrm{At}$ least one post-East River case has refused to apply the exclusion of tort liability for pure economic loss resulting from the defect as such to a consumer transaction. ${ }^{46}$ Another unresolved issue involves the possibility of tort claims not based on strict liability and negligence, for instance fraud and negligent misrepresentation causes of action. It has been argued forcefully that such claims are not affected by the East River restrictions. ${ }^{47}$

In sum, the majority of American courts led by the U.S. Supreme Court is firmly opposed to allowing tort damages for pure economic loss resulting from a product defect. There is, however, one important area in which many courts have made an exception. Where asbestos had to be removed from buildings, the manufacturers have been held liable in tort for the costs of removal if the presence of asbestos could be considered a public safety concern. Not infrequently, judges have tried to rationalize the result in these cases by arguing that the building, viewed as a piece of property separate from the asbestos installed in it, had been "contaminated," and thus there was property damage rather than merely a "pure" economic loss. ${ }^{48}$ But this rationale looks too much like hairsplitting and, if taken seriously, could be said to apply to many other situations as well as to the asbestos cases. For instance, in East River it could be argued that the ships were rendered less useful or, in certain situations like a storm, were rendered completely helpless by the failure of the turbines to function properly, ${ }^{49}$ and thus the ships were "damaged." 50 A better explanation for

44. Supra n. 34.

45. See Spring Motor Distribution v. Ford Motor Co., 489 A.2d 660, 672 (N.J. 1985 ) and the East River case, supra n. 36, at 869 n. 4.

46. See Sherman v. Johnson and Towers Baltimore Inc., 760 F. Supp. 499, 502 (D.Md. 1990). For a critical assessment of this tendency, see O'Donnell, Weiss \& Kaplan, "On the Difference Between Blood and Red Ink: A Second Look at the Policy Arguments for the Abrogation of the Economic Loss Rule in Consumer Litigation," 19 Nova L. Rev. 923 (1995).

47. See Nussbaum, "The Economic Loss Rule and Intentional Torts: A Shield or a Sword?," 8 St. Thomas L. Rev. 474 (1996). It could also be argued that the court's rejection of the "sudden-and-calamitous-event" exception is mere dictum, since the East River case, in the court's view, did not involve such an event.

48. See, for example, City of Greenville v. W.R. Grace \& Co., 827 F.2d 975 ( $4^{\text {th }}$ Cir. 1987), Tioga Public School District No. 15 v. US Gypsum, 984 F.2d 915 ( $8^{\text {th }}$ Cir. 1993).

49. One of the judges on the Court of Appeals in East River, Judge Becker, thought that, for essentially this reason, the complaint stated a cause of action at least with respect to one of the ships which was indeed exposed to a severe storm, see East River, supra n. 36 , at 862. 
the asbestos cases would seem to be the health and safety concerns involved, combined with the fact that typically owners of the buildings affected, especially entities owning schools and other public buildings, will find it hard to carry the costs of removal. ${ }^{51}$ It should be remembered that, in the East River case, the Supreme Court emphasized very much the "reduced" safety concern in cases of injury to the product itself. ${ }^{52}$ While this reduced concern may generally be justified, the asbestos cases can be seen as an exception to this rule.

Finally, it should be mentioned that the current draft of the Third Restatement defines as compensable loss in product liability cases "economic loss if caused by harm to . . the person of another when harm to the other interferes with a legally protected interest of the plaintiff."53 This clause reminds us of the existence, discussed before, ${ }^{54}$ of claims derived from a wrongful death statute or, possibly, the ancient form of action per quod consortium amisit. According to the Draft Restatement, such claims can be asserted if a defective product has caused the death of a close family member or, in states where the consortium protection is still available, has injured a spouse. No direct harm to the plaintiff's person has occurred in these cases. But the statute or the old form of action take the case out of the realm of pure economic loss. ${ }^{55}$

\section{Interference with Use of Resources}

This takes us to a category of cases which the commentators do not usually group together. But the fact patterns we will encounter here have more in common than meets the casual observer's eye. The title chosen for this part of the paper is intended to signal the common denominator here.

50. Sometimes the line between damage to the product itself and damage to other property can be very controversial. In A.J. Decoster Co. v. Westinghouse Elec. Corp., 634 A.2d 1330 (Md. 1994), where a defective switch had caused a ventilating system for a chicken house to fail, suffocating 140,000 chickens, it was held that the purchaser-farmer had not simply lost the benefit of his bargain, but had sustained damage to other property "because that defect is so dangerous in nature;" id. at 1337 . But in Winchester v. Lester's of Minnesota, Inc., $83 \mathrm{~F} .2 \mathrm{~d} 992\left(10^{\text {th }} \mathrm{Cir}\right.$. 1993) when hogs died due to a poorly functioning ventilation system, the purchaser-farmer was held to have no tort claim for property damage under Kansas law, even though the court recognized the "plaintiffs loss of hogs. . .is property damage of a sort," id. at 996 . Remembering the saying about the goose and the gander, one would think that what is a "tort to the chickens" should be a "tort to the hogs."

51. The Wisconsin court in Northridge Co. v. W.C. Grace \& Co., 491 N.W.2d 179 (Wis. 1991), relied more explicitly on such policy grounds than most other asbestos decisions.

52. East River, supra n. 36, at $\mathbf{8 7 1}$. Where, however, a case involves a situation amounting, in the court's view, to a "sudden and calamitous" event, a different assessment appears possible and not foreclosed by East River; see supra n. 47.

53. See Restatement of Torts Third, Proposed Final Draft (1997) \& 21(b), emphasis added. .

54. Text supra at $\mathrm{nn} \cdot 6-8$.

55. See id. comment c. and text supra at nn. 6-8. 
A series of misadventures that one commentator has called "almost comically bizarre" 56 occurred on the Buffalo River in New York during the night of January 21, 1959, giving rise to the case of In re Kinsman Transit Co. which reached the U.S. Court of Appeals for the Second Circuit twice. ${ }^{57}$ As a result of the events of January 21, two ships had crashed into a drawbridge and blocked traffic on the Buffalo River for about two months. When the case reached the court for the second time, it had to decide an issue that has all the earmarks of pure economic loss. Two claimants demanded damages for losses they had suffered because transportation on the river was disrupted, holding liable those whose negligence had caused the mishaps. One of the claimants was under a contractual obligation, as a seller, to deliver wheat from a ship that could not be unloaded because of the obstruction of Buffalo River traffic; the claimant had secured replacement wheat at higher cost to fulfil his duties under the sales contract. The other claimant, a carrier, had committed itself to unload a ship and incurred increased costs because the conditions on the river caused by the accident made the unloading more complicated. The Second Circuit held that neither of these claimants could recover in tort. But instead of invoking the doctrine of no liability for pure economic loss the court determined that the loss was too "remote" or "indirect." The lower court in this case, however, analyzed the situation in terms of "negligent interference with contract" and relied on the Robins Dry Dock case, discussed earlier, ${ }^{58}$ to deny recovery. ${ }^{59}$ In the most interesting passage of its opinion, the Second Circuit said: "[W]e hesitate to accept the 'negligent interference with contract' doctrine in the absence of satisfactory reasons for differentiating contractual rights from other interests which the law protects."60 In other words, the court had serious doubts about the very foundation of the pure economic loss doctrine for which the Robins Dry Dock case stands not as the original, but as the most prominent American authority.

In another water-related set of cases, courts have departed from the doctrine of no liability for economic loss. In Union Oil v. Oppen ${ }^{61}$ a group of commercial fishermen sought recovery for loss of profits resulting from an oil spill in the Santa Barbara Channel on the California coast. The defendants had caused the oil spill in the course of drilling operations carried out on a platform in that Channel. In a well-reasoned opinion the federal court held that, both under maritime and under California law, the defendants were liable to the plaintiffs, since they owed a duty to them "to refrain from negligent

56. See Christie, supra n. 34 , at 536 .

57. See 338 F.2d 708 (2d Cir. 1964) and 388 F.2d 821 (2d Cir. 1968).

58. See supra text with nn. 2 and 3.

59. See the second opinion in In re Kinsman, 388 F.2d 821, at 823.

60. See id.

61. 501 F.2d $558\left(9^{\text {th }}\right.$ Cir. 1974). 
conduct in their drilling operations, which conduct reasonably and foreseeably could have been anticipated to cause a diminution of the aquatic life in the Santa Barbara Channel area and thus cause injury to the plaintiffs' business."62 Relying on California cases such as Biakanja $v$. Irving, one of the intellectual service cases discussed before, ${ }^{63}$ the court found it to be "obvious" that California is quite willing to make exceptions, on policy grounds, to the rule denying recovery for pure economic loss in negligence. ${ }^{64}$ Furthermore, the court was convinced that under California law "the presence of a duty on the part of the defendants in this case would turn substantially on foreseeability,"65 and foreseeability, in the court's view, was not in serious doubt. ${ }^{66}$ Consequently, the fishermen were allowed to recover their lost profits.

There is conflicting authority on whether economic interests other than those of commercial fishermen should enjoy the same protection in the case of water pollution as that obtained by the plaintiffs involved in the Santa Barbara incident. While, for example, the court in Pruitt v. Allied Chemical Corp ${ }^{67}$ granted plaintiffs such recovery, it was denied in State of Louisiana ex rel. Guste v. M/V Testbank.68

Closely related to these water pollution cases is a much discussed New Jersey case in which the plaintiff airline suffered loss of profits due to the evacuation of its offices necessitated by a tank car accident at a nearby railroad yard resulting in the escape of a dangerous chemical. ${ }^{69}$ After carefully reviewing and analyzing the case law, the court concluded that the many exceptions to the rule of no liability for economic loss "expose the hopeless artificiality of the per se rule" and continued: "The scope and number of exceptions, while indepently justified on various grounds, have nonetheles created lasting doubt as to the wisdom of the per se rule of nonrecovery for purely economic losses."70 The New Jersey court saw no need to make physical harm the crucial test of liability for negligence; like the court in Union Oil v. Oppen, it considered foreseeability as a sufficient standard. It emphasized that this standard must be met for a determination both of the existence of a duty owed and of proximate cause between the breach of the duty of care and resultant losses. According to the court, this dual foreseeability requirement provides satisfactory protection

62. Id. at 568 .

63. Text, supra at $\mathrm{nn}$. 22-24.

64. See Union Oil v. Oppen, supra n. 61, at 566 .

65. Id. at 569 .

66. Id.

67. 523 F.Supp. 975 (E.D.Va. 1981).

68. 752 F.2d 1019 (5 ${ }^{\text {th }}$ Cir. 1985).

69. See People Express Airlines, Inc. v. Consolidated Rail Corp., 495 A.2d 107 (N.J. 1985).

70. Id. at 114,115 . 
from the risk of disproportionate liability. ${ }^{71}$ Applying the foreseeability criteria to the facts of the case, the court felt persuaded that a cause of action had been established, but noted that the plaintiff still faced a difficult task in proving damages to the degree of certainty required. ${ }^{72}$

As in the water pollution incidents and in People Express, a temporary interruption of business activities gave rise to another California case. ${ }^{73}$ An action claiming damages for lost profits was instituted by the plaintiff, who operated a restaurant in leased premises, against the lessee's contractor who had delayed completion of improvements to the premises, including renovation of the heating and air conditioning system and installation of insulation. ${ }^{74}$ The Supreme Court of California restated its principles of liability for negligent conduct emphasizing the crucial role of the duty of care and the fact that, under its case law, recovery is not foreclosed "even when only injury to prospective economic advantage is claimed."75 In support of this statement the court referred, in particular, to its precedents in the intellectual services area, among them the Biakanja decision. ${ }^{76}$ It could, of course, also have invoked Union Oil v. Oppen, ${ }^{77}$ a leading case decided under California law, except for the fact that this was a decision by a federal court. An application of the Biakanja criteria led the court to conclude that the defendant owed a duty of care to the plaintiff to complete construction in a manner that would avoid unnecessary injury to the plaintiff's business, where such injury is reasonably foreseeable. ${ }^{78}$ In the court's view, a cause of action had thus been stated, given the (alleged) significant delay in performance by the defendant, (allegedly) causing a significant loss of profits in the plaintiff's restaurant business.

\section{Scholarly Debate}

As the foregoing, by no means exhaustive, survey shows, the American law of liability for purely economic losses is much less well settled and less uniform than one might wish it to be. And the ongoing discussion of the topic in the legal literature does not seem to have provided much helpful guidance for the courts. Only a small number of publications will be discussed here to explain why this is so.

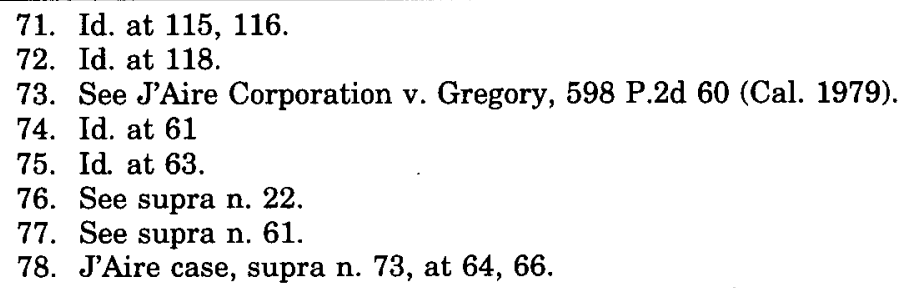


It has been noted repeatedly that the practice which, in many instances, denies recovery for pure economic loss in negligence cases is hard to reconcile with the recovery for potentially large economic losses resulting from negligently caused physical injury. Foreseeability has become the most crucial test to limit the extent of liability for the consequences of negligent conduct resulting in physical injury. More restrictive tests such as privity, used at an earlier stage of the development of the Common Law, have been abandoned. ${ }^{79}$ Thus the question has been asked many times: Why is it that, in the absence of physical injury, most courts still deny recovery for pure economic loss in negligence cases unless one of the numerous exceptions applies?

The argument that purely economic losses are generally unforeseeable has been rejected by one author as quite "unrealistic." ${ }^{\circ 0}$ But the same author argues that there is a good "pragmatic" explanation for the prevailing practice. In his view, the "physical consequences of negligence usually have been limited, but the indirect economic repercussions of negligence may be far wider, indeed virtually openended." 81 In view of today's mass tort cases, which sometimes involve innumerable physically injured victims asserting claims sometimes amounting to millions of Dollars, it is not easy to accept this explanation as satisfactory.

Another rationale advanced by the same author looks to the insurance aspects of purely economic losses. In this regard it is argued that (1) a liability system based on fault and coupled with liability insurance is the most expensive way to administer accident losses and (2) that there are serious practical problems facing insurers in handling insurance against potentially wide, open-ended liability. These considerations are said to support a rule of no liability for pure economic loss coupled with the possibility of first-party loss insurance to be taken out by those whose interests are at risk (at presumably lower cost than liability insurance) ${ }^{82}$ All of the foregoing considerations, however, would seem to be applicable to the whole American accident compensation system relying, as it does, mainly on tort liability and liability insurance rather than social insurance and private first-party insurance. It is indeed an extremely costly system which tends to produce very uneven results and which must sometimes deal with large risks that defy actuarial measurement. All of this is gener-

79. A leading case exemplifying this development is MacPherson v. Buick Motor Co., 111 N.E. 1050 (N.Y. 1916). The earlier restrictive (privity) approach is illustrated by the English case of Winterbottom v. Wright, 152 Eng. Rep. 402 (Ex. 1842) and the New York case of Losee v. Clute, 51 N.Y. 494 (1873).

80. See, for instance, James, "Limitations on Liability for Economic Loss Caused by Negligence: A Pragmatic Appraisal," 25 Vand. L. Rev. 43, 45 (1972).

81. Id. This statement is followed by a reference to the often quoted passage from Cardozo's opinion in Ultramares, also quoted in the text supra at n. 11.

82. Id. at $52,53$. 
ally accepted as true whether or not pure economic loss is recoverable.

Another author has suggested that (1) the pure economic loss cases must be seen as sharing some important similarities with other kinds of non-physical tortious harm and that (2) various types of pure economic loss must be more clearly distinguished from each other. ${ }^{83}$ Emotional distress and consortium cases are said to be non-physical harm cases presenting problems comparable, in certain respects, with pure economic loss problems. Courts have expanded the right to recovery for emotional distress and for loss of consortium in favor of certain relatives of the immediate victim, but not of others, irrespective of foreseeability. ${ }^{84}$ This practice is said to express a concern about "widespread liability." Likewise, in pure economic loss cases such "ripple effect" liability must be avoided by limiting recovery to certain situations within a category that the author defines as "triangular configurations." 85 This term is designed to describe situations like the intellectual services cases discussed earlier in this paper. ${ }^{86}$ The author agrees with those who would allow recovery in a "triangular configuration" only for intended beneficiaries. ${ }^{87}$

Underlying all of these distinctions is once again a belief that widespread liability is a serious concern only in nonphysical harm cases, and that widespread liability is generally of no concern when negligence has caused personal injury or physical damage to property. ${ }^{88} \mathrm{It}$ is significant that the author in his search for a paradigm to demonstrate the limited destructive potential of physical harm situations, comes up with the age-old (privity) case of Winterbottom $v$. Wright ${ }^{89}$ in which a stagecoach broke down due to lack of repairs and, as a consequence, injured the driver..$^{90}$ When this paradigm is used today, it would seem that more than 150 years of rapid industrialization with the attendant phenomenon of mass torts involving physical injuries of sometimes staggering proportions go virtually unnoticed. The author is somewhat closer to this reality in his discussion of a plane crash killing 200 passengers due to a defect in the plane's manufacture caused by a single instance of assembly-line inattentiveness. Here he accepts widespread liability (even though it is arguably dis-

83. See Rabin, "Tort Recovery for Negligently Inflicted Economic Loss: A Reassessment," 37 Stan. L. Rev. 1513 (1985).

84. Id. at $1517-26$.

85. Id. at 1527-34.

86. See supra Part II A.

87. Id. at 1528. Rabin attributes the "intended beneficiary" doctrine to Cardozo, when in fact the New York Court of Appeals under Cardozo's leadership adopted a "quasi-privity" approach; see supra at n. 12. The Second Restatement of Torts, on the other hand, has embraced the "intended beneficiary" idea. See supra Part II A.

88. Id. at $1530,1532$.

89. See supra n. 79.

90. Id. at the top of 1530 . 
proportionate) on the ground that "the victims constitute a single class-they suffer a type of harm in common."91 But certainly a plane crash with 200 victims, a single-event incident, is not the only form of mass disasters and not necessarily the one with the most widespread consequences imaginable. The reality of the most serious mass calamities, as we see it in multi-event product injuries present in DES, asbestos or breast implant cases, is again ignored. ${ }^{92}$ In order to offer a satisfactory explanation for the different treatment of pure economic losses in negligence cases, one would have to face up to these contemporary developments in the realm of physical injuries. Unfortunately, this kind of analysis is missing.

Rather than seeking to explain the rule of no liability for pure economic loss, some authors focus more on the exceptions to the rule. Their search for consistency in the law leads several authors, sympathetic to the "pragmatic concern" which is said to underlie the noliability rule, ${ }^{93}$ to conclude that exceptions should have been made in certain kinds of cases where the rule was in fact applied ${ }^{94}$ Ironically, this includes not only cases like J'Aire, ${ }^{95}$ but also the leading precedent in this area, Justice Holmes's opinion in the Robins Dry Docks ${ }^{96}$ case. The "pragmatic concern" about widespread and open-ended liability has no valid application where, because a lease is in effect, physical damage to property causes the resulting loss to be suffered, due to the terms of the lease, by the lessee and not by the owner. The only serious problem in such a situation is the technical one of deciding which plaintiff(s) - the lessor, the lessee or both jointly-should be given standing. ${ }^{97}$ To the comparatist, it is immediately apparent that courts and writers in other systems have not misconceived this kind of situation as a form of pure economic loss. Realizing that there is, after all, physical damage and there is loss, these foreign courts and observers see the problem as one of attribution, and they have found fairly adequate answers to the questions raised, including the standing issue..$^{98}$

Pursuing the same line of arguments, according to at least one of the authors, another exception from the rule of no liability for pure economic loss should probably be made in cases in which an employer

91. Rabin, supra n. 83 , at 1533.

92. For a description and analysis of such situations under American law, see Peterson \& Zekoll, "Mass Torts," 42 (Supplement) Am. J. Comp. L. 79 (1994).

93. See James, supra n. 80.

94. See James, supra n. 80, at 56, 57. and Schwartz, "The Economic Loss Doctrine in American Tort Law: Assessing the Recent Experience," in Efstathios K. Banakas (ed.), Civil Liability for Pure Economic Loss (1996) at 103, 123-25.

95. See supra $\mathbf{n} .73$.

96. See supra n. 2.

97. Accord, James, supra n. 80 , at 56.

98. Under German law, for example, Schadensliquidation im Drittinteresse is available. 
incurs a loss due to payments to, or on account of, an employee who has suffered a personal injury. ${ }^{99}$ It is argued that, if these payments represent items the employee would be entitled to recover were it not for the payment from the employer, then the "pragmatic objection" to liability for pure economic loss has no legitimate application. ${ }^{100}$ Of course, this suggestion has implications respecting the so-called collateral source rule which require careful consideration. If, however, the suggestion is accepted, the very foundation of the per se rule of no liability for pure economic loss may become questionable.

It is fair to say that most writers are opposed to the tendency exhibited by the California Supreme Court and the New Jersey Supreme Court in many of the cases discussed above, which can be seen as pointing in the direction of a break with the rule. The unanimous opinion of the U.S. Supreme Court in the East River case is sometimes referred to as providing support for a counter trend.101 But the Supreme Court made it clear in East River that it did not decide the issue of whether "a tort cause of action can ever be stated in admiralty when the only damages sought are economic."102 The truth of the matter is that neither East River nor the state law cases involving defective products discussed earlier in this paper ${ }^{103}$ furnish much, if any, arguments for or against the rule denying damages for pure economic loss in negligence cases in general. These cases, when analyzed carefully, merely deal with the issue of whether recovery for damage caused by a defective product, in the absence of physical harm to a person or property, can be based only on the supplier's contract or also on tort, i.e., strict liability or negligence. The majority of courts led by the California Supreme Court in Seely ${ }^{104}$ view the contract set of remedies as exclusive of the tort remedy in these situations, while a strong minority led by the New Jersey Supreme Court ${ }^{105}$ allow a tort action in addition to the contract cause of action, at least in certain situations. Only the minority view includes an implicit exception to the rule of no liability for pure economic loss in negligence (and strict liability) cases. The majority position, on the

99. Traditionally, this situation is seen as undoubtedly subject to the rule; see supra text at n. 5 .

100. See James, supra n. 80, at 57.

101. See, for instance, Christie, supra n. 34, at 537 and George C. Christie et al., Cases and Materials on the Law of Torts 813 ( $\left.3^{\text {rd }} \mathrm{ed} .1997\right)$.

102. See East River case, supra n. 36 , at $871 \mathrm{n}$. 6 . The statement quoted in the text is followed by a "But see ..." referring to Robins Dry Dock. The court was probably aware of the severe criticism of Justice Holmes's opinion discussed above and simply did not want to review the general issue of recovery for pure economic loss.

103. See supra Part II B.

104. See supra n. 32 .

105. See the Santor case, supra n. 34 , as limited in its application to noncommercial cases by the Spring Motors case, supra n. 45 . 
other hand, as Justice Blackmun made clear in East River, is based on the exclusiveness of the contract remedy and nothing else. ${ }^{106}$

But even if Justice Blackmun's opinion does not lend renewed support, in a general way, to the rule against recovery for pure economic loss in negligence, most commentators are less inclined than the highest courts in California and New Jersey to abandon the per se rule in favor of a foreseeability test. More recently, an economic rationale operating with the dichotomy of private loss versus social loss, has been offered by several scholars in defense of the rule against the recent judicial tendencies. ${ }^{107}$ If one accepts this kind of analysis, it could be argued that there should be no recovery for economic loss in a case like J'Aire, ${ }^{108}$ if the business that the restaurant owned by the plaintiff lost went to other restaurants in the neighborhood. If that happened, then there may have been a private loss (the plaintiff's), but no social loss. Other authors, however, even those generally in favor of the no-liability rule, reply that the absence of social loss cannot be the sole determinant of tort damages. Where the plaintiff has suffered private loss, arguments of fairness and justice must also be considered. ${ }^{109}$

For reasons of limitations of space this survey of scholarly contributions must end here. It should at least show why courts and the bar are not really helped very much by the commentators. As long as today's reality of mass torts involving multi-event physical injuries is virtually ignored in the debate of pure economic loss, scholars do not make sense to the practitioners. Also, the academics have not even begun to conceptualize the phenomenon of negligent interference with the use of resources. ${ }^{110}$ Once that concept is accepted, old questions will have to be asked in a different perspective. Why, the question will be, should only an individual right based in private law, as for instance that of a lessee, ${ }^{111}$ deserve protection from such interference? If, on the other hand, certain users of public resources, such as the fishermen in Union Oil v. Oppen, ${ }^{112}$ are entitled to recover for

106. Even with respect to this limited reach, the opinion is not free from confusion; for details, see Schwartz, supra n. 94, at 122-23.

107. See, for example, Bishop \& Sutton, "Efficiency and Justice in Tort Damages: The Shortcomings of the Pecuniary Loss Rule," 15 J. Leg. St. 347 (1986), Goldberg, "Recovery for Economic Loss Following the Exxon Valdez Oil Spill," 23 J. Leg. St. 1 (1994).

108. See supra n. 73.

109. See Schwartz, supra n. 94 , at 128-30.

110. See supra Part II C. An impressive effort has been made, however, to reconceptualize the entire law of "economic negligence;" see Feinman, "Doctrinal Classification and Economic Negligence," 33 San Diego L. Rev. 137 (1996) and the same author's book, supra $\mathrm{n}$. 27. The term "economic negligence" seems to have been introduced into legal discourse by a Canadian author discussing primarily English and Commonwealth law; see Bruce P. Feldthusen, Economic Negligence: The Recovery of Pure Economic Loss (3 $3^{\text {rd }}$ ed. 1994).

111. Like the plaintiff in JAire, supra n. 73.

112. See supra n. 61. 
their pure economic loss, why should other users of public resources, like the claimants in In re Kinsman (No.2), ${ }^{113}$ not be granted recovery? The answer may be that it makes a difference whether the interference with a use of resources effectively shuts down a business, at least temporarily, or just increases the costs of running a business. More probing inquiry is needed, many questions remain.

113. See supra n. 59 . 
